\title{
South China Sea Arbitration and the Protection of the Marine Environment: Evolution of UNCLOS Part XII Through Interpretation and the Duty to Cooperate
}

\author{
Chie Kojima ${ }^{1}$
}

\section{Introduction}

The Arbitral Award of 12 July 2016 in the South China Sea Arbitration ${ }^{2}$ is progressive not only in the sense that it contributed to clarify the definition of an island in international law, but also in the sense that it confirmed that Part XII (Protection and Preservation of the Marine Environment) of the United Nations Convention on the Law of the $\mathrm{Sea}^{3}$ (UNCLOS) can evolve through interpretation and the duty to cooperate. The Award touches upon fundamental questions regarding to what extent Part XII of UNCLOS can interact with other environmental treaty regimes and whether such interaction through interpretation can be seen as an evolution of Part XII of UNCLOS to adapt to new challenges without creating an implementation agreement or amending to UNCLOS. The Award is also illuminating because the Tribunal confirmed that the duty to communicate the results of an environmental impact assessment (EIA) is absolute, regardless of different capacities of States. The Tribunal further alluded to a link between the duty to communicate results of an EIA and the duty to cooperate, which is recognized as a fundamental principle in the protection of the marine environment in international jurisprudence.

This article first provides an overview of the Arbitral Award regarding the protection and preservation of the marine environment. It then analyses the

1 Associate Professor, Faculty of Law, Musashino University, Tokyo, Japan; Ph.D. (Chuo), LL.M. (Yale) and J.s.D. (Yale). The author would like to thank Ms. Katherine Cherry D. Bandanwal for her assistance in research.

2 South China Sea Arbitration (Republic of the Philippines v. People's Republic of China), PCA Case No 2013-19, Judgment, 12 July 2016.

3 United Nations Convention on the Law of the Sea, opened for signature 10 December 1982, 1833 UNTS 3 (entered into force 16 November 1994) (UNCLOS). 
Tribunal's references to the 1992 Convention on Biological Diversity (СвD $)^{4}$ and the 1973 Convention on International Trade in Endangered Species of Wild Fauna and Flora (CITES $)^{5}$ in interpreting Article 192 and 194(5) of UNCLOS. It discusses reasons why the Arbitral Tribunal's application of Article 31(3)(c) of the Vienna Convention on the Law of Treaties ${ }^{6}$ was limited to the clarification of general terminologies such as "ecosystem" and "depleted, threatened or endangered species." The article then examines the Arbitral Tribunal's interpretation of Article 206 of UNCLOS on EIA and the duty to communicate the results of an EIA in the context of the duty to cooperate enshrined as a fundamental principle under Part XII of UNCLOS. Finally, it assesses to what extent the South China Sea Arbitration contributed to advance international marine environmental law and whether it will have impacts on future decision-making.

\section{The Background}

The Philippines made 15 submissions in the South China Sea Arbitration. ${ }^{7}$ Submissions No. 11 and No. 12 (b) were related to the protection of the marine environment in two categories of conduct: fishing practices and construction activities. In Submission No. 11, the Philippines claimed that China had violated its obligations to protect and preserve the marine environment under UNCLOS at Scarborough Shoal, Second Thomas Shoal, Cuarteron Reef, Fiery Cross Reef, Gaven Reef, Johnson Reef, Hughes Reef and Subi Reef, by tolerating and actively supporting environmentally harmful fishing practices undertaken by Chinese fishing vessels at these features. ${ }^{8}$ Submission No. 12 (b) was related to the Philippines' claim that China's construction activities on Mischief Reef, including constructing artificial islands, installations, and structures, violated China's duties under UNCLOS to protect and preserve the marine

4 Convention on Biological Diversity, opened for signature 5 June 1992, 176o UnTS 79, (entered into force 29 December 1993) (CBD).

5 Convention on International Trade in Endangered Species of Wild Fauna and Flora, opened for signature 3 March 1973, 993 UNTS 243 (entered into force 1 July 1975) (CITES).

6 Vienna Convention on the Law of Treaties, opened for signature 23 May 1969, 1155 UNTS 331 (entered into force 27 January 1980).

7 South China Sea Arbitration, supra note 2, at para. 112.

8 Ibid. The original Philippines' Submission No. 11 was related only to Scarborough Shoal and Second Thomas Shoal, but the Tribunal granted the Philippines to amend its Submissions upon its request because the proposed amendment to add six other reefs was "related to or incidental to the Philippines' original Submissions and did not involve the introduction of a new dispute between the Parties" (paras 818-820). 
environment. ${ }^{9}$ The Arbitral Tribunal found that it had jurisdiction for both Submissions 11 and $12(\mathrm{~b}) .{ }^{10}$

With regard to Submission No. 11, the Arbitral Tribunal found that Chinese fishing vessels had engaged in the harvesting of endangered species "on a significant scale", that Chinese fishing vessels had engaged in the harvesting of giant clams "in a manner that was severely destructive of the coral reef ecosystem," and that China was aware of, tolerated, protected and failed to prevent the harmful fishing activities. ${ }^{11}$ The evidence indicated that the China Marine Surveillance (CMS) vessels not only accompanied, escorted and protected the Chinese fishing vessels, but also organized and coordinated their harmful fishing activities. ${ }^{2}$ It was therefore concluded that the activities conducted by these Chinese fishing vessels were attributable to the Chinese Government. ${ }^{13}$ The Tribunal accordingly declared that China breached its obligations to protect and preserve the marine environment under Article 192 and to take all measures to protect and preserve rare or fragile ecosystems and the habitat of depleted, threatened or endangered species and other forms of marine life under Article 194(5) of UNCLOS. ${ }^{14}$

In examining Submission No. 12(b), the Arbitral Tribunal appointed three independent experts, in accordance with Article 24 of the Rules of Procedure, in order to test the reliability of the expert reports submitted by the Philippines ("Carpenter Reports") in the light of China's non-participation in the proceedings. ${ }^{15}$ The experts appointed by the Tribunal jointly submitted their "Assessment of the Potential Environmental Consequences of Construction Activities on Seven Reefs in the Spratly Islands in the South China Sea" (the "Ferse Report"). The Ferse Report concluded that China's construction activities had caused and would cause environmental harm to coral reefs at the seven reefs in the Spratly Island, ${ }^{16}$ which largely confirmed the

Ibid. The Philippine filed an expert report by a reef ecologist in support of its Submission (para. 818).

$10 \quad$ Ibid. at para. 938.

11 Ibid. Dispositif, para. 1203, B(12).

12 Ibid. at paras. 746,749 and 755 .

13 Ibid. at para. 755 .

14 Ibid. Dispositif, para. 1203, B(12).

15 Ibid. at para. 136. Three experts were appointed: Dr. Sebastian C.A. Ferse of the Leibniz Center for Tropical Marine Ecology in Bremen, Germany, Professor Peter J. Mumby and Dr. Selina Ward of the School of Biological Sciences at the University of Queensland, Australia.

16 Cuarteron Reef, Fiery Cross Reef, Gaven Reef, Johnson Reef, Hughes Reef, Mischief Reef, and Subi Reef. 
conclusions reached in the Carpenter Reports. ${ }^{17}$ Furthermore, despite China's assertion that its land reclamation activities were based on "thorough studies and scientific proof,"18 only a 500-word statement made by the State Oceanic Administration of China (SOA) and a slightly longer report prepared by researchers of SOA were identified during the proceedings. China failed to respond to the Tribunal's request to provide a copy of an EIA. Consequently, the Arbitral Tribunal found that China's reclamation and construction of artificial islands, installations, and structures at the above seven reefs had caused "severe, irreparable harm to the coral reef system," that China had not cooperated or coordinated with the neighboring States in the South China Sea concerning the protection and preservation of the marine environment in relation to its construction activities, and that China had failed to communicate an assessment of the potential effects of such activities on the marine environment. ${ }^{19}$ The Tribunal therefore held that China breached its obligations to cooperate with States bordering an enclosed or semi-enclosed sea under Article 123 of UNCLOS, to protect and preserve the marine environment under Article 192 of UNCLOS, to take all measures necessary to prevent, reduce and control marine pollution under Article 194(1) of UNCLOS, to take all measures to protect and preserve rare or fragile eco-systems and the habitat of depleted, threatened or endangered species and other forms of marine life under Article 194(5) of UNCLOS, to cooperate on a global or regional basis for the protection and preservation of the marine environment under Article 197 of UNCLOS, and to conduct environmental impact assessments and communicate reports of the results of such assessments under Article 206 of UNCLOs. ${ }^{20}$

Although much attention has been paid to what the Arbitral Award said with regard to interpretation of Article 121 of UNCLOS concerning the regime of islands and rocks, the above conclusion of the Tribunal regarding the protection of the marine environment should not be underestimated for the development of international marine environmental law. The following sections examine the reasoning of the Arbitral Tribunal in finding that China had violated its obligation to protect the marine environment under UNCLOS.

\section{Evolutionary Interpretation of UNCLOS Part XI I}

In examining the Philippines' claim that China violated its obligations to protect and preserve the marine environment under UNCLOS by tolerating and

\footnotetext{
17 South China Sea Arbitration, supra note 2, at paras. 979-980.

18 Ibid. at para. 920.

19 Ibid. Dispositif, para. 1203, B(13).

20 Ibid.
} 
actively supporting environmentally harmful fishing practices undertaken by Chinese fishing vessels, it was necessary for the Arbitral Tribunal to interpret the meaning of framework provisions such as Articles 192 and 194(5) of UNCLOS in the light of other treaty regimes, namely, the CBD and CITES. This section analyses the implications of importing outside norms into Part XII of UNCLOS through the principle of "systematic integration"21 expressed under Article 31(3)(c) of the Vienna Convention on the Law of Treaties.

The interaction of UNCLOS with other treaty regimes indicates the unique character of UNCLOS as a "living" instrument. It must be reminded that, while UNCLOS is considered to be the "Constitution of the Oceans," ${ }^{22}$ it is a widely held view that its interpretation and application are considered flexible and responsive to emerging problems. ${ }^{23}$ UNCLOS codified a number of customary rules on the one hand, but it also provides "umbrella or framework provisions [...] capable of being implemented at a later date" on the other hand. ${ }^{24}$ Therefore, the South China Sea Arbitration is only an example where UNCLOS continues to evolve through various techniques, which include references to "international rules and standards established through competent international organizations" in its provisions, ${ }^{25}$ the adoption of an implementing agreement, ${ }^{26}$ and the evolutionary interpretation/application of norms

21 International Law Commission, Fragmentation on International Law: Difficulties Arising from the Diversification and Expansion of International Law, Report of the Study Group of the International Law Commission Finalized by Martti Koskenniemi, un Doc. A/CN.4/L.682 (13 April 2006), available at: legal.un.org/ilc/documentation/english/a cn4_1682.pdf, paras 410-423.

22 United Nations, A Constitution for the Oceans: Remarks by Tommy T.B. Koh, of Singapore, President of the Third United Nations Conference on the Law of the Sea, 6 and 11 December 1982, available at: www.un.org/depts/los/convention_agreements/texts/koh_english.pdf.

23 Alan Boyle, Further Development of the Law of the Sea Convention: Mechanisms for Change 54 International and Comparative Law Quarterly, 563-584 (2005). See also, Jill Barrett and Richard Barnes, LaW of the Sea: unclos as a Living TreaTY (2016).

24 Cameron Jefferies, Marine Mammal Conservation and the Law of the Sea (2016), at 37 .

25 E.g., Articles 211, 213, 214, 216, 217, 218, 222 of UNCLOS.

26 Agreement Relating to the Implementation of Part XI of the United Nations Convention on the Law of the Sea of 10 December 1982 (with annex), opened for signature 28 July 1994, 1836 UNTS 3 (entered into force (provisionally) 16 November 1992, (definitively) 28 July 1996); Agreement for the Implementation of the Provisions of the United Nations Convention on the Law of the Sea of 10 December 1982 relating to the Conservation and Management of Straddling Fish Stocks and Highly Migratory Fish Stocks, opened for signature 4 August 1995, 2167 UNTS 3 (entered into force 11 December 2001). 
through the principle of systematic integration. ${ }^{27}$ How UNCLOS can evolve through interpretation is exemplified in the South China Sea Arbitration as discussed below.

\section{$1 \quad$ Article 192 and Other Applicable Rules of International Law}

The Arbitral Award indicated the relationship between Part XII of UNCLOS and other applicable rules of international law in order to state the specific content of Article 192 of UNCLOS. Article 192 provides the most general obligation in Part XII of UNCLOS; it reads, "States have the obligation to protect and preserve the marine environment."

When considering the Philippines' claims that China failed to protect and preserve the marine environment through harmful fishing practices and construction activities, the Arbitral Tribunal noted that the content of Article 192 was informed by other provisions of Part XII including Article 194 and "other applicable rules of international law." 28 The Tribunal emphasized that a State could violate Article 192 not only by harming the marine environment but also by failing to take active measures to protect and preserve the marine environment. ${ }^{29}$ As stated in the Advisory Opinion in Legality of the Threat of Use of Nuclear Weapons, ${ }^{30}$ the Arbitral Tribunal reiterated a due diligence obligation that States must ensure that activities within their jurisdiction and control respect the environment of other States or of areas beyond national control. ${ }^{31}$ This obligation originates from the Trail Smelter case ${ }^{32}$ and predates UNCLOS as a customary international rule. ${ }^{33}$ The Tribunal further pointed to more recent cases such as the Iron Rhine Arbitration ${ }^{34}$ and reiterated that States have a "positive" duty to prevent or mitigate significant harm to the environment when engaging in large-scale construction activities, as opposed to a "negative" duty not to degrade the environment. ${ }^{35}$ This positive

27 Boyle, supra note 23 , at 566 . Boyle wrote, "UNCLOS is a treaty which functions within a larger legal system."

28 South China Sea Arbitration, supra note 2, at para. 941.

29 Ibid.

$30 \quad$ Legality of the Threat of Use of Nuclear Weapons (Request for Advisory Opinion), Advisory Opinion of 8 July 1996, ICJ Reports 1996, para. 29.

31 South China Sea Arbitration, supra note 2, at para. 941.

32 Trail Smelter Arbitration (United States v. Canada), Award of 11 March 1941, III RIAA 1905.

33 Philippe Sands, Principles of International Environmental LaW (2003), at 242.

34 Iron Rhine Arbitration (Belgium v. Netherlands), Award of 24 May 2005, XXVII RIAA 35, para. 59 .

35 South China Sea Arbitration, supra note 2, at para. 941. 
duty was declared as a principle of general international law in the Iron Rhine Arbitration, i.e., a customary rule that was crystalized after the adoption of UnCLOS. Accordingly, the phrase "other applicable rules of international law" is interpreted to encompass both treaties and customary international law. Customary international law comprises a customary rule established after the adoption of UNCLOS in 1982 within and beyond the context of the law of the sea.

In determining the content of Article 192, the Arbitral Tribunal referred to Article 237 of UNCLOS, having implied that specific obligations included in other international agreements that were concluded previously or later than UNCLOS would also fall under the scope of Part XII including Article 192. ${ }^{36}$ Article 237 of UNCLOS is generally construed as a provision harmonizing conflict between treaties as generally envisaged in Article 30 of the Vienna Convention on the Law of Treaties. A general interpretation of Article 237 is that "all future agreements that are compatible with UNCLOS are allowed and in the case of incompatibility, the obligations stemming from UNCLOS prevail." ${ }^{37}$ It appears, however, that the Tribunal went one step further and considered Article 237 as a provision positively linking the general obligations of Part XII of UNCLOS and specific obligations under other international agreements that are previously or subsequently concluded. The reference to Article 237 by the Arbitral Tribunal indicates the Tribunal's positive attitude towards the principle of systematic integration in interpreting UNCLOS. ${ }^{38}$

2

UNCLOS Art 194(5), CBD, and CITES

Article 194(5) of UNCLOS provides that measures to protect and preserve the marine environment include "those necessary to protect and preserve rare or fragile ecosystems as well as the habitat of depleted, threatened or endangered species and other forms of marine life." The Tribunal considered that the conservation of marine living resources forms a part of the protection and preservation of the marine environment and that Article 192 includes "a due

\footnotetext{
$36 \quad$ Ibid. at para. 942.

37 Malgosia Fitzmaurice and Olufemi Elias, Contemporary Issues in the LAW OF Treaties (2005) at 335 .

38 Further question might arise as to whether any later agreement, concluded by some or all of the parties to UNCLOS for the purpose of adapting its general rules to a specific region or a specific topic, can be considered as an agreement implementing a framework provision of UNCLOS. For a discussion on this broad understanding of an implementation agreement to UNCLOS, see, Chie Kojima and V.S. Vereschchetin, Implementation Agreements, in Rüdiger Wolfrum (ed), Max Planck Encyclopedia of Public INTERNATIONAL LAW, VOL. V (2012) 110-116.
} 
diligence obligation to prevent the harvesting of endangered species that are recognized internationally as being at risk of extinction and requiring international protection."39

There is no definition provided in UNCLOS of an "ecosystem" or what species are included in "rare and fragile ecosystems," but the Tribunal stated that Article 2 of the CBD, which defines an ecosystem as "a dynamic complex of plant, animal and micro-organism communities and their non-living environment interacting as a functional unit", is an internationally accepted definition. ${ }^{40}$ The Tribunal stated that the marine environments where China's harmful activities took place constituted "rare and fragile ecosystems" under Article 194(5) and were habitats of "depleted, threatened or endangered species" which included the giant clam, the hawksbill turtle and certain species of coral and fish, as supported by the scientific evidence presented by both the Carpenter Reports and Ferse Report. ${ }^{41}$

In examining Submission No. 11 concerning China's failure to control harmful fishing practices by its nationals, the Arbitral Tribunal considered Appendixes of CiTEs to identify whether the species such as sea turtles (Cheloniidae) and giant clams (Tridacnidae) harvested by Chinese fishing vessels were indeed threatened or endangered..$^{42}$ The Arbitral Tribunal emphasized that CiTES was the "subject of nearly universal adherence" and informed the content of Articles 192 and 194(5) of UNCLOS. ${ }^{43}$ Although sea turtles and giant clams were under different levels of international protection under the Appendixes to CiTEs, the Tribunal concluded that not only sea turtles listed under Appendix I to CITES but also giant clams harvested from Scarborough Shoal, the Spratly Islands and many of the corals found in the Spratly Islands, as listed under Appendix II to CITES, were unequivocally threatened. ${ }^{44}$ It must be noted that species under Appendix I and II to CITES are updated through adding, removing, or moving species between Appendix I and II by the Conference of the Parties to cites, either at its regular meetings or by postal procedures. Therefore, the Arbitral Tribunal's references to CiTEs indicate an example whereby the content of UNCLOS can be updated or revised over time by interacting with other treaty regimes existing at the time.

39 South China Sea Arbitration, supra note 2, at para. 956.

$40 \quad$ Ibid. at para. 945 .

$41 \quad$ Ibid. at para. 945 .

42 Ibid. at paras. 956-957.

$43 \quad$ Ibid. at para. 956.

$44 \quad$ Ibid. at para. 957. 
The universal character of $\mathrm{CBD}$ and CITES is an important element for assessing whether updating the content of UNCLOS by an international decision can be widely supported by the international community, or at least by all States parties to UNCLOS. In other words, the interpretation should be acceptable for both China and the Philippines at least, ${ }^{45}$ both of which were parties to the $\mathrm{CBD}$ and CITES at the time, but it should also reflect expectations of the international community. While UNCLOS has an "innovative, complex yet flexible system of dispute settlement" in order to address new challenges that were not foreseen or addressed during its drafting process, ${ }^{46}$ an act of clarifying the meaning of UNCLOS provisions through interpretation should be satisfactory to all States parties to UNCLOS in order to maintain the integrity and universality of UNCLOS. ${ }^{47}$

With regard to measuring and assessing universality of these instruments, СвD had 196 Parties and Cites 183 Parties when the Tribunal rendered the Award. In the Award, the Tribunal explicitly stated that cites formed part of the "general corpus of international law" with "universal adherence" that informs the content of certain obligations under UNCLOS. ${ }^{48}$ The Tribunal similarly emphasized the general character of Свр by expressing the definition of ecosystem under СBD as the "internationally accepted definition." ${ }^{\text {"9 }}$ These references to the universality of CBD and CITES would set certain standards for future decisions by international courts and tribunals.

By referring to other international agreements, the Arbitral Tribunal relied on the principle of systematic integration provided under Article 31(3)(c) of the Vienna Convention on the Law of Treaties. Article 31(3)(c) of the Vienna Convention provides that "any relevant rules of international law applicable in the relations between the parties" must be taken into account together with the context in interpreting a treaty. The Tribunal, at the same time, followed international jurisprudence concerning the application of Article 31(3)(c) with caution.

As Alan Boyle writes, the jurisprudence on Article 31(3)(c) has been "narrowly circumscribed."50 An example is the Shrimp-Turtle case before the wTO

45 Boyle argued that when another treaty is referred in interpreting UNCLOS, the "level of participation in that treaty cannot be ignored" as it proves that the treaty has "the consensus support of all the parties, or there is no objection." Boyle, supra note 23, at 571. Shunji Yanai, Can the UNCLos Address Challenges of the 21st Century? 57 German YeARBOOK OF INTERNATIONAL LAW 43-62 (2014) at 45.

47 Boyle, supra note 23, at 569.

48 South China Sea Arbitration, supra note 2, at para. 956.

49 Ibid. at para. 945.

5o Boyle, supra note 23 , at 567 . 
Appellate Body in which UNCLOs, Agenda 21, CBD, and Resolution on Assistance to Developing Countries, adopted in conjunction with the Convention on Conservation of Migratory Species were referred to in determining whether living natural resources can be included in the meaning of "exhaustible natural resources" under Article XX $(\mathrm{g})$ of the GATT $1994 \cdot{ }^{51}$ It was remarkable that the Appellate Body stated that the generic term "natural resources" in Article Xx(g) was "by definition, evolutionary."52 Boyle observed that such references are not general revision or re-interpretation of a treaty, but rather an incorporation of the existing general international law. ${ }^{53}$ The South China Sea Arbitration indicated that generic terms included in UNCLOS can similarly have an active interaction with general international law and evolve through interpretation.

IV Environmental Impact Assessment (EIA) and the Duty
to Cooperate under UNCLOS

In examining Submission No. 12(b) related to China's construction activities, the Arbitral Tribunal extensively relied on the Ferse Report in order to judge its environmental impact. The Tribunal accepted the conclusion of the Ferse Report that "China's recent construction activities [had] and [would] cause environmental harm to coral reefs" at the Reefs where the island-building activities took place.$^{54}$ The Tribunal found that China violated Articles 192, 194(1), 194(5), 197, 123, and 206 of UNCLOS. This section highlights the reasoning of the Tribunal concerning the interpretation of Articles 197, 123 and 206 and discusses whether the duty to communicate the results of an EIA can be related to the duty to cooperate enshrined as a fundamental principle under Part XII of UNCLOS.

\section{$1 \quad$ EIA under Article 206 of UNCLOS}

Although the history of EIA started as a domestic rule only in $1969,{ }^{55}$ a number of multilateral environmental agreements since the early 1980 s stipulate the obligation to conduct an EIA. It is a widely supported view that the duty to

\footnotetext{
$51 \quad$ For more analysis, see ibid. at 567-568. Import Prohibition of Certain Shrimp and Shrimp Products, wTo Appellate Body (1998) WT/DS58/AB/R, at paras 130-131.

$52 \quad$ Ibid. at para. 130.

53 Boyle, supra note 23, at 568 .

54 South China Sea Arbitration, supra note 2, para. 979.

55 The United States' National Environmental Policy Act of 1969. See generally, Astrid Epiney, Environmental Impact Assessment, in Rüdiger Wolfrum (ED), MAX Planck Encyclopedia of Public International LaW, Vol. III (2012), 580-592, at para.3.
} 
carry out an EIA is customary international law. ${ }^{56}$ The obligation to assess the potential effects of planned activities on the marine environment is stipulated under Article 206 of UNCLOS as follows:

When States have reasonable grounds for believing that planned activities under their jurisdiction or control may cause substantial pollution of or significant and harmful changes to the marine environment, they shall, as far as practicable, assess the potential effects of such activities on the marine environment and shall communicate reports of the results of such assessments in the manner provided in Article 205.

Article 206 does not indicate the specific meaning of "substantial pollution of or significant and harmful changes to the marine environment" or what is required in an EIA or the manner in which an EIA should be conducted. Furthermore, there is no reference to "international rules and standards established through competent international organizations" unlike some other framework provisions in Part XII. ${ }^{57}$ The only procedure stipulated under UNCLOS is that States must publish reports of the results of an EIA to the competent international organizations, which will be disclosed to all States, under Article 205 of UNCLOS.

In the South China Sea Arbitration, the Arbitral Tribunal reiterated that the obligation to conduct an EIA was a direct obligation under the UNCLOS and a general obligation under customary international law as confirmed in the Advisory Opinion on the Responsibilities and Obligations of States with respect to Activities in the Area by the International Tribunal for the Law of the Sea (ITLOS) in 2011. ${ }^{58}$ The customary nature of the obligation to conduct an EIA was also confirmed in Pulp Mills on the River Uruguay in 2010, in which the International Court of Justice described EIA as "a practice, which in recent years has gained so much acceptance among States that it may now be considered a requirement under general international law." 59

Although Article 206 of UNCLOS contains an element of discretion for States as expressed in the terms "reasonable" and "as far as practicable," the Arbitral Tribunal opined that the obligation to communicate reports of the

$56 \quad$ Ibid. at paras. 49 and 64 .

57 See supra note 25 .

58 South China Sea Arbitration, supra note 2, at para. 948; Responsibilities and Obligations of States with respect to Activities in the Area, Advisory Opinion of 1 February 2011, ITLOS Reports 2011, at para. 145 .

59 Pulp Mills on the River Uruguay (Argentina v. Uruguay), Judgment of 20 April 2010, ICJ Reports 2010, at para. 204. 
results of the assessments was "absolute." 60 This remark highlights the importance of Article 206 in connection to the due diligence obligation under Article 194(2). ${ }^{61}$ In further clarifying the meaning of the obligation to communicate under Article 206, the Tribunal stated that simple assertions produce no proof of actual conduct. ${ }^{62}$ The Tribunal insisted that China's repeated assertions that it had undertaken thorough environmental studies were not sufficient to meet the obligation not only to conduct an EIA, but also to communicate it, under Article 206. ${ }^{63}$ The Chinese Delegation at the 25th Meeting of States Parties to the UNCLOS held in June 2014 only stated that China's construction activities followed "a high standard of environmental protection" although the Tribunal did not find any written assessment submitted to the meeting or any other international body. Furthermore, China did not respond to the Tribunal's request to submit a copy of any EIA.

The Tribunal went a step further and evaluated whether China acted in compliance with its own domestic law, the EIA Law of 2002, and whether what was argued by China met the standards of the international jurisprudence. The Tribunal concluded that the SOA statement and soA report fell short of China's own legislative standards and were "far less comprehensive" than EIAs reviewed by other international courts and tribunals or EIAs filed in the foreign construction projects which were referred in the soA report. ${ }^{64}$ Although these examinations were unnecessary to find a breach of Article 206 in the present case, it is remarkable that the Tribunal alluded to the existence of a certain international standard that an EIA should meet under international law, despite the absence of explicit requirements in Article 206 of UNCLOS. This may be regarded as another example of evolutionary interpretation of UNCLOS.

\section{Duty to Cooperate and Duty to Communicate}

The Award in the South China Sea Arbitration is significant in the sense that the Tribunal underlined the importance of the duty to cooperate. ${ }^{65}$ The Arbitral Tribunal reiterated that the duty to cooperate is "a fundamental principle in

\footnotetext{
6o South China Sea Arbitration, supra note 2, at para. 948.

61 Ibid.

$62 \quad$ Ibid. at para. 989 .

$63 \quad$ Ibid. at para. 991.

64 Ibid. para. 990. The Tribunal cited Pulp Mills on the River Uruguay (Argentina v. Uruguay) and Australia's Final Environmental Impact Statement for the proposed Abbot Point Growth Gateway Project (footnote 1189).

65 Seegenerally, Rüdiger Wolfrum, Cooperation, International Law of, in RÜDIGER WOLFRUM (ed.) Max Planck Encyclopedia of Public International LaW Vol. II (2012) 783-792.
} 
the prevention of pollution of the marine environment under Part XII of the Convention and general international law" as repeatedly confirmed in the jurisprudence of ITLOS. ${ }^{66}$ China had a duty to cooperate under Articles 197 and the duty to coordinate under Article $123 .{ }^{67}$ Article 197 stipulates the duty to cooperate, on a global or regional basis, directly or through competent international organizations in developing international rules, standards and recommended practices and procedures. The duty to cooperate under Article 123 is stipulated weakly, stating that States bordering an enclosed or semi-enclosed sea "should" cooperate and they "shall" endeavor to coordinate.

The origin of the duty to cooperate derives from Principle 7 of the Rio Declaration on Environment and Development, which reads: "States shall co-operate in a spirit of global partnership to conserve, protect and restore the health and integrity of the Earth's ecosystem." The duty to cooperate is an evolving norm, but functions actively in some fields of international law. Rüdiger Wolfrum, therefore, distinguished a general obligation to cooperate as integrated in the Charter of the United Nations from the obligation to cooperate in specific areas of international law, such as spaces beyond national jurisdiction, international environmental law, the protection of human rights and international economic law. ${ }^{68}$ In the context of international environmental law, the duty to cooperate serves as "the driving force for the progressive development" of universal environmental agreements having the character of framework agreements, which develops "through additional instruments such as protocols or measures." 69

UNCLOS is not a so-called framework agreement that requires the adoption of protocols for its implementation, but a number of provisions in Part XII of UNCLOS can are of the character of framework provisions to be developed progressively and to be implemented through a separate agreement. For example, Part XII envisages the development of international rules and standards through competent international organizations or general diplomatic conference as stipulated for example in Article 211(1) concerning vessel-source marine pollution. It is reasonable to consider that the duty to cooperate is similarly the driving force for the progressive development of Part XII UNCLOS. In addition to the positive role of the duty to cooperate in international law-making, the

66 South China Sea Arbitration, supra note 2, at para. 946. Mox Plant (Ireland v. United Kingdom), Provisional Measures, Order of 3 December 2001, ITLOS Reports 2001, para. 82.

$67 \quad$ Ibid. at paras. 946, 984-986.

68 Wolfrum, supra note 65.

$69 \quad$ Ibid. at para. 31. 
duty also plays a role in the prevention of future environmental harm in cases of provisional measures before international courts. ${ }^{70}$

How does the duty to cooperate play a role in the operation of procedural rules of international law? What is the relationship between the duty to communicate the result of an EIA and the duty to cooperate? The Tribunal did not find any convincing evidence that China attempted to coordinate or cooperate with other States bordering the South China Sea. ${ }^{71}$ The Arbitral Tribunal then clearly stated that " $[\mathrm{t}]$ his lack of coordination [was] not unrelated to China's lack of communication."72 In this statement, the Tribunal seemed to avoid referring to "cooperation" weakly formulated in Article 123 with "should." Rather, it emphasized that China failed to endeavor to coordinate with other States directly or through a regional organization in a manner consistent with the "shall" text of Article 123. It can also be observed that China's failure to communicate with any of the Tribunal, Meeting of States Parties to the UNCLOS, or any other international organization, undermined the fundamental principle of cooperation enshrined not only in Article 123 but also in Part XII of UNCLOS. China's breach of the duty to cooperate is further duplicated by its non-participation in the proceedings, as parties to a dispute are under a general obligation to cooperate before and during the proceedings with the body to which a dispute has been submitted. ${ }^{73}$

\section{Conclusion}

The implications of the South China Sea Arbitration to international marine environmental law are twofold: first, the Award provides an example whereby Part XII of UNCLOS can be linked to other environmental treaty regimes through interpretation; second, the Award gives a part of the picture of how the duty to cooperate emerges and operates in relation to other duties under Part XII of UNCLOS; in other words, how Part XII evolves through the duty to cooperate.

The first implication is related to the unique character of UNCLOS considered to be a "Constitution of the Oceans" but flexible and responsive to

\footnotetext{
$70 \quad$ Alan Boyle, 'The Environmental Jurisprudence of the International Tribunal for the Law of the Sea, 22 International Journal of Marine and Coastal LaW, 369-381 (2007), at 378 .

71 South China Sea Arbitration, supra note 2, at para. 986.

72 Ibid.

73 Wolfrum, supra note 65 , at para. 38 .
} 
emerging problems as a living instrument. Potentially, a number of conventions could be similarly taken into account in clarifying the numerous generic terms under UNCLOS that are not defined. Even if UNCLOS provides a definition such as in the case of the term "marine pollution", its meaning needs to be updated as time passes to address new challenges. For instance, the protection of the marine environment from global climate change cannot be solved without interpreting the UNCLOS provisions in accordance with the Montreal Protocol on Substances that Deplete the Ozone Layer, ${ }^{74}$ the United Nations Framework Convention on Climate Change (UNFCCC) ${ }^{75}$ and its associated international agreements.

Does the South China Sea Arbitration demonstrate a way for Article 192 of UNCLOS to become a weapon against every threat to the marine environment? At least, it clearly indicated that the content of Article 192 is informed by the provisions of Part XII and other applicable rules of international law. Accordingly, in the Award, a due diligence obligation to prevent the harvesting of endangered species including giant clams and sea turtles was deduced from Articles 192 and 194(5) in the light of СвD and Cites. There is no doubt that Article 192 is a framework provision that requires living interpretation in the light of the developments in international law.

The second implication is related to an evolution of UNCLOS Part XII through the duty to cooperate. The importance of the duty to cooperate has been recognized especially in the field of international environmental law where rules and principles continue to develop and where compliance with these rules and principles is brought by cooperation rather than liability. The Arbitral Tribunal's emphasis on the importance of cooperation, coordination and communication endorses the existence of this duty to cooperate as a fundamental principle of Part XII as well as a principle under general international law, whose scope of application is wider than the explicit formulation of the duty to cooperate under Articles 123 and 197 of UNCLOS.

74 Montreal Protocol on Substances that Deplete the Ozone Layer, opened for signature 16 September 1987, as amended, 1522 UNTS 3 (entered into force 1 January 1989).

75 United Nations Framework Convention on Climate Change, opened for signature 9 May 1992, 31 ILM 849 (entered into force 21 March 1994) (UNFCCC). 